\title{
PROBLEMATIKA PENDIDIKAN MULTIKULTURAL DI SEKOLAH TINGKAT SMK
}

\author{
Havifah Husnatul Khatimah \\ Jurusan Matematika, FMIPA, Universitas Negeri Padang \\ E-mail : Havifahhusnatul@gmail.com
}

\begin{abstract}
Abstrak
Pendidikan multikultural adalah sebuah konsep yang dibuat dengan tujuan untuk menciptakan persamaan peluang pendidikan bagi semua siswa yang berbeda-beda ras, etnis, kelas sosial dan kelompok budaya, dan untuk membantu semua siswa agar memperoleh pengetahuan, sikap dan keterampilan yang diperlukan dalam menjalankan peran-peran seefektif mungkin pada masyarakat demokratik-pluralistik serta diperlukan untuk berinteraksi, negosiasi, dan komunikasi dengan warga dari kelompok beragam agar tercipta sebuah tatanan masyarakat bermoral yang berjalan untuk kebaikan bersama. Melalui pendidikan multicultural peserta didik diharapkan memiliki kompetensi yang baik, bersikap dan menerapkan nilai-nilai demokratis, humanisme dan pluralisme di sekolah dan di luar sekolah. Pendidikan multikultural diberikan kepada siswa SMK agar mereka memahami bahwa di dalam lingkungan mereka dan di lingkunganlain terdapat keragaman budaya yang berpengaruh terhadap tingkah laku, sikap, pola pikir manusia sehingga manusia tersebut memiliki cara-cara, kebiasaan, aturan-aturan bahkan adat istiadat yang berbeda satu sama lain. Bila perbedaan itu tidak dapat dipahami dengan baik dan diterima dengan bijaksana, maka konflik akan mudah terjadi baik di lingkungan sekolah maupun di lingkungan masyarakat.
\end{abstract}

Kata kunci : praktek dan problematik, pendidikan multikultural, SMK

\section{Pendahuluan}

Undang-undang Dasar 1945 (Pasal31 ayat 3), dengan tegas menunjukkan bahwa arah dan tujuan pendidikan nasional adalah peningkatan iman dan takwa serta pembinaan akhlak mulia para peserta didik. Keluarnya Undang-undang Sistem Pendidikan Nasional (Sisdiknas), yakni UU No. 20 Tahun 2003, menegaskan kembali fungsi dan tujuan pendidikan nasional tersebut. Pada Pasal 3 UU ini ditegaskan, Pendidikan nasional berfungsi mengembangkan kemampuan dan membentuk watak serta peradaban bangsa yang bermarta-bat dalam rangka mencerdaskan kehidupan bangsa, bertujuan untuk berkembangnya potensi peserta didik agar menjadi manusia yang beriman dan bertakwa kepada Tuhan Yang Maha Esa, berakhlak mulia, sehat, berilmu, cakap, kreatif, 
mandiri, dan menjadi warga negara yang demokratis serta bertanggung ja-wab. Sisdiknas merupakanacuan untuk men-didik dan membangun manusia seutuhnya. Dalam Sisdiknas pasal 4, tercantum pula prinsip-prinsip penyelenggaraan pendi-dikan, yaitu: (1) Pendidikan diselenggarakan secara demokratis dan berkeadilan serta tidak diskriminatif dengan menjunjungtinggi hak asasi manusia, nilai keagamaan, nilai kultural, dan kemajemukan bangsa, (2) Pendidikan di-selenggarakan sebagai satu kesatuan yang sistemik dengan sistem terbuka dan multi-makna, (3) Pendidikan diselenggarakan seba-gai suatu proses pembudayaan dan pember-dayaan peserta didik yang berlangsung sepan-jang hayat, (4) Pendidikan diselenggarakan dengan memberi keteladanan, membangun kemauan, dan mengembangkan kreativitas peserta didik dalam proses pembelajaran, (5) Pendidikan diselenggarakan dengan mengem-bangkan budaya membaca, menulis, dan ber-hitung bagi segenap warga masyarakat, dan (6) Pendidikan diselenggarakan dengan mem-berdayakan semua komponen masyarakat melalui peran serta dalam penyelenggaraan dan pengendalian mutu layanan pendidikan. Dari paparan di atas, sebenarnya pe-merintah Indonesia sudah memberikan ruang yang cukup untuk terselenggaranya pendidikan nasional yang sesuai dengan kebhinekaan bangsa Indonesia. Seperti kita ketahui bahwa Indonesia adalah salah satu negara yang multikultural terbesar didunia, kebenaran dari pernyataan ini dapat dilihat dari sosio kultur maupun geografis yang begitu beragam dan luas. Di wilayah NKRI terdapat sekitar kurang lebih13.000 pulau besar dan kecil, dan jumlah penduduk kurang lebih 240juta jiwa,terdiri dari 300 suku bangsa yang menggunakan hampir 200 bahasa yang berbeda. Selain itu juga menganut agama dan kepercayaan yang beragam seperti Islam, Katholik, Kristen Protestan, Hindu, Budha, dan Konghucu, serta berbagai macam kepercayaan. Akan tetapi banyak orang yang belum juga menyadari bahwa kemajemukan tersebut juga menyimpan potensi konflik yang dapat mengancam kehidupan berbangsa dan ber-negara. Keragaman ini diakui atau tidak, akan dapat menimbulkan berbagai persoalan seperti yang sekarang dihadapi bangsa ini. Korupsi, kolusi, nepotisme, premanisme, perseteruan politik, kemiskinan, kekerasan, separatisme, perusakan lingkungan, dan hilangnya rasa kemanusiaan. Salah satu institusi pendidikan di Indonesia yang banyak diberitakan di media massa dengan berbagai perilaku negatifnya adalah Sekolah Menengah Kejuruan (SMK), di antaranya adalah perkelahian antar geng (seperti geng motor), tawuran massal antar sekolah yang kerap terjadi, bahkan dengan berbagai senjata tajam yang banyak disita polisi, dan sebagainya.Untuk mengatasi problema tersebut harus dilakukan melalui pendidikan, dengan cara membangun kultur pendidikan nilai di sekolah. Oleh sebab itu adalah sangat penting untuk menanamkan pendidikan nilai di SMK, untuk mencegah terjadinya perilaku yang tidak diinginkan. Berkaitan dengan hal ter-sebut, untuk membangun rasa kebersamaan, sekaligus menjawab berbagai problematika kemajemukan seperti yang digambarkan di atas dibutuhkan suatu langkah yang siste-matis.Dalamtulisaninipenulis menawarkan satu alternatif sebagai suatu upaya untuk mengatasi problema melalui 
penerapan kon-sep pendidikan multikulturalyang berbasis pada pemanfaatan keragaman yang ada di masyarakat, khususnya yang ada pada siswa seperti keragaman etnis, budaya, bahasa, aga-ma, status sosial, gender, kemampuan, umur dan ras. Konsep pendidikan multikultural ini bertujuan agar siswa SMK memiliki kesadar-an berperilaku humanis, pluralis, dan demo-kratis.Pentingnya pendidikan multikulturaldiberikan kepada siswa SMK dengan harapan agar mereka mampu memahami bahwa di dalam lingkungan mereka dan juga di lingkungan lain terdapat keragaman budaya. Keragaman budaya tersebut berpengaruh ter-hadap tingkah laku, sikap, pola pikir manusia sehingga manusia tersebut memiliki cara-cara (usage), kebiasaan (folk ways), aturan-aturan (mores) bahkan adat istiadat (customs) yang berbeda satu sama lain. Bila perbedaan itu tidak dapat dipahami dengan baik dan diterima dengan bijaksana, maka konflik (seperti perkelahian antar pelajar) akan mudah terjadi baik di lingkungan sekolah maupun di ling-kungan masyarakat.Lingkungan pendidikan SMKadalah sebuah sistem yang terdiri dari banyak faktor, seperti: kultur sekolah, kebijakan sekolah, serta formalisasi kurikulum dan bidang studi. Bila dalam hal tersebut terjadi perubahan maka hendaklah perubahan itu fokusnya un-tuk menciptakan dan memelihara lingkungan SMK dalam kondisi multikultural yang efektif. Tujuan utama dari pendidikan multi-kultural adalah mengubah pendekatan pela-jaran dan pembelajaran ke arah memberi peluang yang sama pada setiap siswa. Jadi tidak ada yang dikorbankan demi persatuan. Siswa ditanamkan pemikiran lateral, keanekaragaman, dan keunikan itu dihargai. Ini berarti harus ada perubahan sikap, perilaku, dan nilai-nilai khususnya civitas akademika SMK.

\section{Pembahasan}

\section{Pengertian Pendidikan Multikultural.}

Menurut Brant dalam Billilng \& Gillborn (2004, p.37) multikulturisme difokuskan untuk menyediakan informasi dan me-ningkatkan kesadaran tentang etnisisme, budaya, kesetaraan, kesalahpahaman prejudice, dan kebodohan.

Pendidikan multikultural sebagai sebuah kebijakan sosial yang didasarkan pada prinsip-prinsip pemeliharaan budaya dan saling memiliki rasa hormat antara seluruh kelompok budaya di dalam masyarakat. Pendidikan multikultural pada dasarnya merupakan program pendidikan bangsa agar komu-nitas multikultural dapat berpartisipasi dalam mewujudkan kehidupan demokrasi yang ideal bagi bangsanya (Banks, 2007).

${ }^{1}$ Banks mengatakan bahwa pendidikan multikultur dapat didefinisikan menurut tiga hal, yaitu ide atau konsep (idea or concept), gerakan reformasi (reform movement), dan

\footnotetext{
${ }^{1}$ Banks, James A. (2007). Educating citizens in a multicultural society. New York: Teacher College Press.
} 
proses berkelanjutan (ongoing process).Sebagai ide, pendidikan multikulturalmengandung makna bahwa semua peserta didik, tanpa memper-hatikan gender, status sosial, suku, ras atau karakteristik budaya, wajib memperoleh kesempatan yang sama untuk belajar di sekolah. Sebagai gerakan reformasi, pendidikan multi-kultur dirancang untuk membuat perubahan di sekolah dan isntitusi pendidikan sehingga seluruh peserta didik dari semua kelas sosial, gender, ras, dan kelompok budaya dapat memperoleh kesempatan yang sama untuk belajar. Sebagai proses berkelanjutan, pen-didikan multikulturaladalah proses terus me-nerus diterapkan di segala aspek pendidikan di sekolah dengan tujuan persamaan hak mem-peroleh pendidikan dan meningkatkan prestasi akademik untuk mencapai potensi tertinggi dirinya sebagai manusia (the highest poten-tials as human beings) yang mungkin tidak pernah tercapai sempurna tapi tetapterus diupayakan (Banks, 2007, p.82).

Tujuan pendidikan multikultur menurut Banks (2002, pp.1-2) ${ }^{2}$ adalah: 1) untuk mem-bantu individu mendapatkan pemahaman diri yang lebih besar dengan melihat diri dari sudut pandang budaya lain; 2) untuk mem-berikan siswa suatu alternatif budaya dan etnis; 3) untuk menyediakan keterampilan, sikap, dan pengetahuan yang dibutuhkan semua siswa untuk berfungsi dalam budaya etnis mereka,dalam budaya mainstream, dan dalam dan lintas budaya etnis lainnya; serta 4) untuk mengurangirasa sakit dan diskriminasi bahwa pengalaman anggota dari beberapa kelompok etnis dan ras karena karakteristik unik mereka ras, fisik, dan budaya.

Zamroni (2011, p.152) ${ }^{3}$ mengemukakan beberapa tujuan yang akan dikembangkan pa-da diri siswa dalam proses pendidikan multi-kultural, yaitu:

$>$ Siswa memiliki critical thinkingyang kuat, sehingga bisa mengkaji materi yang disampaikan secara kritis dan konstruktif

> Siswa memiliki kesadaran atas sifat curiga atas pihak lain yang dimiliki, dan mengkaji mengapa dan dari mana sifat itu muncul, serta terus mengkaji bagaimana cara meng-hilangkan sifat curiga tersebut.

> Siswa memahami bahwa setiap ilmu bagai-kan sebuah pisau bermata dua, ada sisi baik dan ada sisi buruk. Semua tergantung pada yang memiliki ilmu tersebut.

> Siswa memiliki keterampilan untuk me-manfaatkan dan mengimplementasikan ilmu yang dikuasai.

${ }^{2}$ Banks, James A. (2002). An introduction to multicultural education. Boston: Allyn \& Bacon.

${ }^{3}$ Zamroni. (2011). Pendidikan demokrasi pada masyarakat multikultural. Yogyakarta: gavin Kalam Utam 
> Siswa bersifat sebagai a learning person, belajar sepanjang hayat masih di kandung badan.

> Siswa memiliki cita-cita untuk menempati posisi sebagaimana ilmu yang dipelajari. Namun, juga menyadari bahwa posisi ter-sebut harus dicapai dengan kerja keras.

> Siswa dapat memahami keterkaitan apa yang dipelajari dengan kondisi dan persoalan yang dihadapi bangsa.

Berdasarkan pendapat dari para ahli di atas, dapat dikatakan bahwa pendidikan multikultural adalah sebuah konsep yang dibuat dengan tujuan untuk menciptakan persamaan peluang pendidikan bagi semua siswa yang berbeda-beda ras, etnis, kelas sosial dan kelompok budaya. Tujuan penting lainnya dari konsep pendidikan multikulturaladalah untuk membantu semua siswa agar memperoleh pengetahuan, sikap dan keterampilan yang diperlukan dalam menjalankan peran-peran seefektif mungkin pada masyarakat demokratik-pluralistik serta diperlukan untuk berinteraksi, negosiasi, dan komunikasi dengan warga dari kelompok beragam agar ter

Melalui pendidikan multikultural peserta didik diharapkan dapat dengan mudah memahami, menguasai, memiliki kompetensi yang baik, bersikap dan menerapkan nilainilai demokratis, humanisme dan pluralisme di sekolah dan di luar sekolah. Pendidikan di alam demokrasi seperti Indonesia harus berorientasi pada kepentingan bangsa yang berlatar belakang multietnic,multireligion,Multilanguage dan lain-lain. Hal ini berarti bahwa penyelenggara pendidikan harus memperhatikan ragam kon-disi bangsa yang heterogen.

\section{Paradigma Pendidikan Multikultural}

Banks $\left(1993\right.$, p.3) ${ }^{4}$ menyatakan bahwa pendidikan multicultural secara umum sebagai pendidikan untuk people of color, artinya pendidikan multikultural ingin mengeksplo-rasi perbedaan sebagai keniscayaan. Pendidik-an multikultural adalah ide atau falsafah sebagi suatu rangkaian kepercayaan dan pen-jelasan yang mengakui dan menilai penting-nya keragaman budaya, identitas pribadi, kesempatan pendidikan dari individu, kelom-pok maupun negara. Lebih lanjut Banks (2001, p.28) menyatakan bahwa pendidikan multikultural adalah konsep atau ide sebagai suatu rangkaian kepercayaan (set of believe) dan penjelasan yang mengakui dan menilai pentingnya keragaman budaya dan etnis dalam membentuk gaya hidup, pengalaman sosial, identitas pribadi dan kesempatan-kesempatan pendidikan dari individu, kelom-pok maupun negara.

\footnotetext{
${ }^{4}$ Banks, James A. (1993). Teaching strategies for ethnic studies. Boston: Allyn and Bacon Inc.
} 
Pendidikan multikultural adalah suatu kebijakan yang lahir dari kesadaran yang mendalam bahwa masyarakat harus menghar-gai dan menjunjung tinggi adanya berbagai perbedaan, antara lain realitas keberadaan berbagai macam etnis, suku bangsa, bahasa, dan kultur masyarakat, sehingga memerlukan keberadaan sistem dan praktek pendidikan yang bersifat adil setara sehingga semua siswa tanpa melihat latar belakangnya bisa men-dapatkan pelayanan pendidikan yang layak untuk mencapai prestasi optimal. Keberadaan sistem dan praktek pendidikan semacam ini merupakan prasyarat mewujudkan masyarakat yang demokratis. Mewujudkan pendidikan yang demokratis memerlukan beberapa per-syaratan pokok antara lain: a) praktik pen-didikan di sekolah-sekolah dilaksanakan ber-dasarkan pada prinsip keadilan dan kesetara-an; b) proses pembelajaran dijauhkandari sifat bias dan stereotip; dan c) Proses pembelajaran harus berujung pada pengembangan kemampuan kultural pada diri siswa (Zamroni, 2011, pp.33-34). ${ }^{5}$

Zamroni (2011, pp.147-148) menyatakan bahwa pendidikan multikulturaladalah suatu gerakan pembaharuan dan proses untuk menciptakan lingkungan pendidikan yang se-tara untuk seluruh siswa, yang memiliki prinsip sebagai berikut: a) pendidikan multi-kultural adalah gerakan politik yang bertujuan menjamin keadilan sosial bagi seluruh warga masyarakat tanpa memandang latar belakang yang ada; b) pendidikan multikultural me-ngandung dua dimensi: level kelas, yakni pembelajaran, dan level sekolah, yakni kelem-bagaan, antara keduanya tidak bisa dipisah-kan, tetapi justru harus ditangani lewat refor-masi yang komprehensif; c) pendidikan multi-kultural menekankan pada perlunya analisis kritis atas sitem kekuasaan dan privilages untuk dapat dilakukannya reformasi kompre-hensif dalam pendidikan; d) tujuan pendidikan multikultural adalah menyediakan bagi setiap siswa jaminan memperoleh kesempatan guna mencapai prestasi maksimal sesuai dengan kemampuan, minat, dan bakat yang dimiliki; e) pendidikan multikultural merupakan pendi-dikan yang baik untuk seluruh siswa, tanpa memandang latar belakangnya.

paradigma pendidikan multikulturalsebagai berikut: a) pendidikan multikultural bisa menjadi jantungbagi proses untuk menciptakan kesetaraan pendidikan bagi seluruh warga masyarakat; b) pendidikan multikultu-ral bukan sekedar dari perubahan kurikulum atau perubahan metode pembelajaran; c) pendidikan multikultural sebagai proses transformasi kesadaranyang memberikan arah ke mana transformasi praktek pendidikan harus menuju; dan d) pendidikan multikultural bertujuan untuk membangun jembatan antara kurikulumdankarakterguru,pedagogik,iklim kelas, dan kultur sekolah guna membangun visi sekolah yang menjunjung kesetaraan.

${ }^{5}$ Zamroni. (2011). Pendidikan demokrasi pada masyarakat multikultural. Yogyakarta: gavin Kalam Utam 
Pendidikan multikultural merupakan proses pengembangan sikap dan tata laku se-seorang atau sekelompok orang dalam usaha mendewasakan manusia melalui upaya pengajaran, pelatihan, proses, perbuatan, dan cara-cara mendidik yang menghargai pluralitas dan heterogenitas secara humanistik.Pendidikan multikultural mengandung arti bahwa proses pendidikan yang diimplementasikan pada ke-giatan pembelajaran di satuan pendidikan selalu mengutamakan unsur perbedaan sebagai hal yang biasa, sebagai implikasinya pen-didikan multikultural membawa peserta didik untuk terbiasa dan tidak mempermasalahkan adanya perbedaan secara prinsip untuk ber-gaul dan berteman dengan siapa saja tanpa membedakan latar belakang budaya, suku bangsa, agama, ras, maupun adat istiadat yang ada.

\section{Pentingnya Pendidikan Multikultural di Indonesia}

Indonesia merupakan sebuah bangsa yang mempunyai banyak sekali keragaman, baik dari segi suku bangsa, agama, ras, mau-pun golongan. Keragaman yang ada tersebut sangat memungkinkan terjadinya sikap-sikap primordialisme maupun etnosentrisme yang dapat memicu konflik. Apabila keragaman tersebut mampu dilihat sebagai kekayaan sosiol budaya, maka akan menuju pada integrasi bangsa. Namun sebaliknya, apabila keragaman yang dipicu oleh sikap primordial dan etnosentris tersebut tidak bisa ditanggulangi dengan baik, maka bukan tidak mungkin akan memunculkan disintegrasi bangsa.

Salah satu contoh keragaman yang dipicu oleh sikap primordial dan etnosentris tersebut tidak bisa ditanggulangi dengan baik, yaitu di kota Padang "Kondisi ekonomi nelayan yang miskin di kota Padang berpengaruh terhadap gizi keluarga, kesehatan keluarga, perubutan sumber daya perikanan menciptakan kontestasi dan konflik terbuka, pembakaran kapal trawl, dan kesenjangan ekonomi yang semakin tajam justru semakin memperparah kemiskinan nelayan tradisional di Kota. Hebatnya persaingan ekonomi dan perangkap kemiskinan di kalangan nelayan tradisional" (M.Hidayat,2018) ${ }^{6}$

Pemahaman dan akselarasi pendidikan yang berbasis multikultural menjadi sangat penting untuk dihayati bagi generasi muda. Terutama untuk diaplikasikan dalam kehidupan sehari-hari. Pemahaman dari awal mengenai multikultural setidaknya akan mempenga-ruhi perkembangan generasi muda Indonesia di masa yang akan datang. Oleh karena itu proses pendidikan yang berbasis multi-kultural, tidak saja berlangsung di sekolah namun juga luar sekolah yakni dimasyarakat dan keluarga. Dengan demikian diharapkan akan terjadi kerukunan antara suku/etnik yang berbeda-beda dan secara

${ }^{6}$ Hidayat, M. (2018). Problematika Internal Nelayan Tradisional Kota Padang: Studi Faktor-Faktor Sosial Budaya Penyebab Kemiskinan. Socius, 4(1), 31-40.

Doi:10.24036/Scs.V4i1.15 
bersama-sama mem-bangun bangsa dan negara yang tercinta Indonesia.

Di lain pihak, kita menyadari bahwa interaksi dengan budaya global merupakan keniscayaan yang tidak perlu ditakutkan, justru semestinya dapat dimanfaatkan untuk memperkaya nilai-nilai sosial budaya dengan nilai-nilai luhur yang bersifat universal. Hal ini menunjukan sifat keterbukaan yang dimiliki oleh sistem sosial budaya kita belum sepenuhnya dapat dimanfaatkan secara tepat dan produktif.

Oleh karena itu, untuk memunculkan sikap toleransi, serta saling memahami dalam konteks lintas budaya, maka perlu diberlakukan suatu sistem pendidikan yang multikultur. Pendidikan multikultur ini mempunyai peran yang sangat strategis dalam membekali seseorang menghadapi era globalisasi sehingga tidak hanyut dalam dampak negatif globalisasi. Selain itu pula pendidikan multikulturalini berperan untuk menyatukan budaya bangsa, dalam arti tidak menjadikan budaya yang ada menjadi seragam, namun keberagaman yang dipandang sebagai kekayaan bangsa yang patut dijaga bersama. Jika peran dan tujuan tersebut tercapai secara maksimal, maka integrasi, persatuan dan kesatuan bangsa Indonesia akan tercapai.

\section{Karakteristik Pendidikan Nilai di SMK}

Pendidikan nilai-nilai di Sekolah Menengah Kejuruan (SMK) harus memberikan akses dan kesempatan kepada peserta didik untuk mempraktekkan dan menerapkan jenis pengetahuan, kompetensi, dan sikap dalam proses mempersiapkan mereka untuk hidup di masyarakat yang kompleks saat ini. SMK harus memiliki kepedulian dan mempromosi-kan nilai-nilai pendidikan, keunggulan dan standar yang tinggi sebagai aspirasi individu dan kelembagaan, berprestasi dan melakukan dalam semua aspek kegiatannya. SMK harus humanis dan memberikesempatan yang luas kepada peserta didik untuk mendapatkan nilai-nilai yang akan sangat penting dalam pengembangan pribadi dan sosial. Sekolah harus mengembangkan rasa kemerdekaan dan harga diri peserta didik sebagai manusia, me-miliki kepercayaan diri untuk berkontribusi pada masyarakat, menjadi bagian dari masya-rakat dalam tatanan kehidupan sosial politik yang berbudaya dan bermoral.

SMK harus mempersiapkan masa depan peserta didik sebagai anggota masyarakat dan warga negara untuk melakukan hubungan interpersonal satu sama lain, dengan cara yang tidak bertentangan dengan norma dalam masyarakat SMK harus menyiapkan peserta didik untuk memiliki ke-pedulian kepada pendidikan multikulturaldi samping pendidikan keterampilan. SMK harus menggabungkan pendidikan untuk otonomi pribadi yang rasional, pengembangan pendidikan multikultural dan berkontribusi sosial untuk kebahagiaan, kesejahteraan, dan ke-damaian. 


\section{Praktik dan Problematik Pembelajaran Pendidikan Multikultural dan Upaya Sistematis Untuk Mengatasinya}

Dalam kerangka strategi pembelajaran, pembelajaran berbasis multikultural diharapkan dapat mendorong terjadinya proses imajinatif, metaforik, berpikir kreatif dan sadar budaya. Namun pada prakteknya, penggunaan budaya lokal (etnis) dalam pembelajaran berbasis multikultural tidak terlepas dari berbagai problematik yang terdapat dalam setiap kom-ponen pembelajaran, sejak persiapan awal dan implementasinya. Beberapa permasalahan awal pembelajaran berbasis multikultural pada tahap persiapanawal, antara lain: 1) guru kurang mengenal budayanya sendiri, budaya lokal maupun budaya peserta didik; 2) guru kurang menguasai garis besar struktur dan budaya etnis peserta didiknya, terutama dalam konteks mata pelajaran yang akan diajar-kannya; dan 3) rendahnya kemampuan guru dalam mempersiapkan peralatan yang dapat merangsang minat, ingatan, dan pengenalan kembali peserta didik terhadap khasanah bu-daya masing-masing dalam konteks budaya masing-masing dalam konteks pengalaman belajar yang diperoleh.

Untuk mengaktualisasikan pendidikan multicultural haruslah memperhatikan berbagai dimensi yang saling berelasi satu sama lain. Banks (2007, pp.83-85) memberikan panduan dimana ada lima dimensi pendidikan multikultur yang seharusnya secara simultan dilakukan, yaitu: integrasi materi (content integration), prosespembentukan pengetahu-an (knowledge construction process),reduksi prasangka (prejudice reduction),pendidikan/ perlakuan pedagogi tanpa pandang bulu (equity pedagogy),dan pemberdayaan budaya sekolah dan struktur sosial (empowering school culture and social structure).

Integrasi konten adalah upaya guru memberikan atau menggunakan contoh dan materi dari berbagai budaya dan kelompok untuk mengajarkan konsep kunci, prinsip, generalisasi, teori dan lain-lain ketika mengajar satu topik atau mata pelajaran tertentu. Dimensi ini digunakan oleh guru untuk memberikan keterangan dengan „poin kunci"pembelajaran dengan merefleksi materi yang berbeda-beda. Secara khusus, para guru menggabungkan kandungan materi pembela-jaran ke dalam kurikulum dengan beberapa cara pandang yang beragam. Salah satu pendekatan umum adalah mengakui kontribu-sinya, yaitu guru-guru bekerja ke dalam kuri-kulum mereka dengan membatasi fakta tentang semangat kepahlawanan dari berbagai kelompok. Di samping itu, rancangan pembe-lajaran dan unit pembelajarannya tidak diru-bah. Dengan beberapa pendekatan, guru menambah beberapa unit atau topik secara khusus yang berkaitan dengan materi multi-kultural. Sebagai contoh, ketika guru SMK mengajar topik menggambar motif batik, kemudian dikaitkan dengan berbagai macam motif batik di berbagai daerah penghasil batik di Indonesia. Artinya, yang dimaksud dengan integrasi konten adalah mengintegrasikan pendidikan multikultur ke dalam mata pelajaran/topik pelajaran. Dengan kata lain, sambil belajar biologi, terjadi penyadaran akan perbedaan budaya.

Akan tetapi dapat timbul problematik dalam "seleksi dan integrasi isi" (content selection and integration) mata pelajaran, yaitu: a) sejauh mana guru mampu memilih aspek dan unsur budaya yang relevan dengan isi dan topik mata pelajaran;dan b) sejauh mana guru dapat mengintegrasikan budayalokal dalam mata pelajaran yang diajarkan, sehingga pembelajaran lebih bermakna bagi peserta didik. Sebagai upaya untuk mengatasi problematik tersebut, penulis menawarkan beberapa petunjuk untuk 
membantu guru dalam mengintegrasikan isi tentang kelompok etnis ke dalam pembelajaran dalam pendidik-an multikultural, yaitu: 1) guru dituntut un-tuk mempunyai pengetahuan yang luas tentang beragam budaya; 2 ) sensitif dengan sikap dan perilaku rasial, gender, status sosial, dan lainnya; 3 ) membawa citra positif tentang berbagai kelompok etnis; 4) menggunakan buku, film, video, dan rekaman yang dijual di pasaran untuk pelengkap buku teks dari kelompok etnis dan menyajikan perspektif kelompok etnis pada siswa; 5) berbagi kisah etnis dan budaya dengan siswa; 6) sensitif dengan tahap perkembangan dari siswa; dan 7) gunakan teknik belajar yang kooperatif dan kerja kelompok untuk meningkatkan integrasi ras, etnis, dan status sosial di sekolah dan di kelas

Proses pembentukan pengetahuan adalah suatu dimensi dimana para guru mem-bantu siswa untuk memahami beberapa perspektif dan merumuskan kesimpulan yang dipengaruhioleh disiplin pengetahuan yang mereka miliki. Dimensi ini juga berhubungan dengan pemahaman para pelajar terhadap perubahan pengetahuan yang ada pada diri mereka sendiri.Dimensi ini berupaya membantu siswa untuk memahami, mencari tahu, dan menentukan bagaimana suatu pengeta-huan atau teori pada dasarnya secara implisit tercipta karena adanya pengaruh budaya tertentu, kalangan tertentu, kelompok dengan status sosial tertentu yang terjadi pada saat itu. Sebagai contoh, ketika guru SMK membahas topik tentang Galileo yang menghasilkan teori heliosentris yang menumbangkan asumsi geosentris yang terjadi pada masa dimana pengaruh agama saat itu sangat dominan. Sehingga, Galileo harus dihukum mati karena teorinya, namun belakangan teori tersebut dipakai oleh masyarakat dunia. Di sini guru harus menjelaskan mengapa hal itu sampai terjadi dengan mengungkapkan pengaruh budaya masyarakat di sana pada waktu itu.

Problematik yang dapat timbul pada dimensi proses pembentukan pengetahuan adalah: a) kurangnya pengetahuan guru dalam memilih aspek budaya yang tepat sehingga dapat membantu peserta didik untuk mema-hami konsep kunci secara lebih tepat; dan b) kurangnya pengetahuan guru dalam meng-gunakan frame of reference dari budaya tertentu dan mengembangkannya dalam per-spektif ilmiah. Yang dapat dilakukan guru untuk mengatasi masalah tersebut adalah: a) menambah wawasan dengan membaca buku, atau penelurusan internet, dan b) melatih pe-ngembangan frame of referencedari budaya dalam perspektif ilmiah melaui diskusi dengan guru lain atau kelompok kerja guru.

Reduksi prejudice adalah upaya guru membantu siswa mengembangkan sikap positif terhadap perbedaan (baik dari sisi suku, budaya, ras, gender, status sosial, dll.) Sebagai contoh, adalah tidak benar kalau guru men-dorong sikap atau prasangka yang meng-anggap bahwa orang Papua yang berkulit hitam adalah terbelakang, bodoh dan lain-lain. Prejudice yang tidak benar terhadap gender, ras, budaya dan lain-lain dalam proses inter-aksi di sekolah inilah yang harus dihindari.

Problematik yang dapat muncul dalam dimensi ini adalah kurangnya perhatian/sensifitas guru dalam meluruskan prejudicenegatif yang dapat terjadi di kalangan siswa. Upaya yang harus dilakukan guru untuk mengatasi problematik tersebut adalah guru berkewajiban meluruskan asumsi dan pre-judicenegatif seperti itu. Salah satu cara mengurangi prejudiceini adalah dengan meli-batkan siswa melakukan aktifitas bersama dengan mereka yang terdiri dari berbagai status sosial, ras, gender dan lain-lain. Dalam dimensi ini guru dituntut untuk melakukan banyak usaha dalam 
membantu siswa me-ngembangkan perilaku positif tentang per-bedaan kelompok. Sebagai contoh, ketika siswa SMK masuk sekolah dengan perilaku negatif dan memiliki kesalah-pahaman ter-hadap ras atau etnik yang berbeda dan kelompok etnik lainnya, pendidikan dapat membantu siswa mengembangkan perilakuintergroup yang lebih positif, penyediaan kondisi yang mapan dan pasti. Dua kondisi yang dimaksud adalah bahan pembelajaran yang memiliki citra yang positif tentang perbedaan kelompok dan menggunakan bahan pembelajaran tersebut secara konsisten dan terus-menerus. Penggunaan teksbookmulti-kultural atau bahan pengajaran lain dan stra-tegi pembelajaran yang kooperatif diharapkan dapat membantu para pelajar untuk mengembangkan perilaku dan persepsi terhadap ras yang lebih positif. Jenis strategi dan bahan dapat menghasilkan pilihan para pelajar untuk lebih bersahabat dengan ras luar, etnik dan kelompok budaya lain.

Perlakuan pedagodik tanpa pandang bulu (equity pedagogy) adalah upaya guru memperlakukan secara sama tanpa pandang bulu dalam proses pembelajaran di kelas. Dimensi ini memperhatikancara-cara dalam mengubah fasilitas pembelajaran sehingga mempermudah pencapaian hasil belajar pada sejumlah siswa dari berbagai kelompok. Strategi dan aktivitas belajar di SMKdiupa-yakan memperlakukan pendidikan secara adil, antara lain dengan bentuk kerjasama (coope-ratve learning), dan bukan dengan caracara yang kompetitif (competition learning). Hal ini juga menyangkut pendidikan yang diran-cang untuk membentuk lingkungan SMK, menjadi banyak jenis kelompok, termasuk ke-lompok etnik, wanita, dan para pelajar dengan kebutuhan khusus yang akan memberikan pe-ngalaman pendidikan persamaan hak dan persamaan memperoleh kesempatan belajar. Hal ini akan terlihat dari metode yang di-gunakan, cara bertanya, penunjukkan siswa, pengelompokkan siswa, dan sebagainya.

Problematik yang dapat timbul dalam equity pedagogyini adalah apabila guru terlalu banyak memakai budaya etnis atau kelompok tertentu dan (secara tidak sadar) menafikan budaya kelompok lain. Yang harus dilakukan guru dalam hal ini adalah guru harus berupaya untuk memiliki "khasanah budaya” mengenai berbagai unsur budaya dalam tema tertentu.

Pemberdayaan budaya sekolah dan struktur sosial adalah proses merestrukturisasi dan reorganisasi sekolah sehingga siswa dari beragam ras, suku, kelas sosial akan men-galami dan merasakan pemberdayaan dan persamaan budaya. Dimensi inipenting dalam memperdayakan budaya siswa yang dibawa ke sekolah yang berasal dari kelompok yang berbeda.

Dalam menyusun struktur sosial SMKmemanfaatkan potensi budayasiswa yang beranekaragam sebagai karakteristik struktur SMK setempat, misalnya berkaitan dengan praktik kelompok, iklim sosial, latihan-latihan, partisipasi ekstra kurikuler dan peng-hargaan staff dalam merespon berbagai perbe-daan yang ada di SMK. Dengan demikian, semangat multikulturalisme harus tercermin dalam segala aktifitas di SMK. Hal ini menun-tut adanya perubahan baik dari sisi literasi multikultur pendidik dan tenaga kependi-dikan, kebijakan sekolah, struktur organisasi, iklim sekolah dan lain-lain.

Banks (2002, pp.30-32) ${ }^{7}$ mengemukakan empat pendekatan yang mengintegrasikan ma-teri pendidikan multikulturalke dalam kuri-kulum ataupun

\footnotetext{
${ }^{7}$ Banks, James A. (2002). An introduction to multicultural education. Boston: Allyn \& Bacon.
} 
pembelajaran di sekolah yang bila dicermati relevan untuk diimplementasi-kan di sekolah di SMK, yaitu: 1) pendekatan kontribusi (the contributions approach);2) pendekatan Aditif (Aditive Approach);3) pen-dekatan transformasi (the transformation ap-proach); dan 4) pendekatan aksi sosial (the social action approach).

Pendekatan kontribusi (the contri-butions approach) paling sering dilakukan dan paling luas dipakai dalam fase pertama dari gerakan kebangkitan etnis.Substansi pendidikan multikulturalpada tahap ini adalah menanamkan pada siswa bahwa manusia yang hidup di sekitarnya dan di tempat lain serta di dunia ini sangat beragam. Seperti berbagai jenis makanan, pakaian, dan lain-lain dari berbagai daerah. Dengan demikian siswa me-ngerti bahwa ada cara yang berbeda tetapi maksud dan nilainya sama. Sehingga mereka dapat belajar untuk menerima perbedaan dengan proses dan rasa yang menyenangkan. Akhirnya siswa merasa berbeda itu bukanlah masalah, tetapi anugerah.

Pada Pendekatan aditif (aditive ap-proach) dilakukan penambahan materi, konsep, tema, dan perspektif terhadap kuriku-lum tanpa mengubah struktur, tujuan dan karakteristik dasarnya. Pendekatan aditif ini sering dilengkapi dengan penambahan buku (cerita rakyat dari berbagai daerah atau negara lain), media pembelajaran berbasis multikul-tural misalnya CD pembelajaran cerita ber-bagai daerah/negara, modul pendidikan multi-kultural, atau bidang bahasan terhadap kuriku-lum tanpa mengubahnya secara substansif. Hal ini dilakukan untuk menanamkan penge-tahuan yang luas bagi siswa. Rasa ketertarikan akan keragaman yang diperoleh di dalam kelas akan memotivasi siswa untuk tahu lebih banyak dengan membaca, melihat di internet, berkunjung, bertanya pada yang lebih tahu dan sebagainya. Dengan wawasan yang lebih luas tentang keragaman budaya, kehidupan, persahabatan, pengetahuan, siswa akan tum-buh menjadi orang yang inklusif, mudah menerima yang berbeda, toleran dan meng -hargai orang lain. Selain itu akan mudah berinteraksi dengan lingkungan yang baru ataupun yang kompleks.

Pendekatan tranformasi (the transfor-mation approach) berbeda secara mendasar dengan pendekatan kontribusi dan aditif. Pada pendekatan transformasi mengubah asumsi dasar kurikulum dan menumbuhkan kompe-tensi siswa dalam melihat konsep, isu, tema, dan problem dari beberapa perspektif dan sudut pandang etnis. Bank (1993) ${ }^{8}$ menyebut ini proses multiple acculturation sehingga rasa saling menghargai, kebersamaan dan cinta sesama dapat dirasakan melalui pengala-man belajar. Konsepsi akulturasi ganda (multiple acculturation conception) dari ma-syarakat dan budaya negara mengarah pada perspektif bahwa memandang peristiwa etnis, sastra, musik, seni dan pengetahuan lainnya sebagai bagian integral dari yang membentuk budaya secara umum. Budaya kelompok dominan hanya dipandang sebagai bagian dari keseluruhan budaya yang lebih besar.

Pendekatan aksi sosial (the social action approach) mencakup semua elemen dari pendekatan transformasi, namun menam-bah komponen yang mempersyaratkan siswa membuat aksi yang berkaitan dengan konsep, isu atau masalah yang dipelajari dalam unit. Tujuan utama dari pengajaran dalam pende-katan ini adalah mendidik siswa melakukan untuk kritik sosial dan mengajari mereka keterampilan pembuatan keputusanuntuk memperkuat siswa dan membantu mereka memperoleh pendidikan

\footnotetext{
${ }^{8}$ Banks, James A. (1993). Teaching strategies for ethnic studies. Boston: Allyn and
} Bacon Inc. 
politis, sekolah mem-bantu mereka menjadi kritikus sosial yang reflektif dan partisipan yang terlatih dalam perubahan sosial. Siswa memperoleh pengeta-huan, nilai, dan keterampilan yang mereka butuhkan untuk berpartisipasi dalam peruba-han sosial sehingga kelompok -kelompok etnis, ras, dan golongan-golongan yang tera-baikan dan menjadi korban dapat berparti-sipasi penuh dalam masyarakat.

Dalam mengimplementasikan pendekatan-pendekatan pendidikan multicultural sebagaimana diuraikan di atas, banyak bergantung pada peran dan kemampuan guru dalam multikulturalisme. Karena itu peran guru di dalam pendidikan multikultural di sekolah sangatlah penting. Adapun peran guru yang relevan diterapkan di SMKadalah sebagai berikut.

\section{Membangun Paradigma Keberagamaan Inklusif di Lingkungan Sekolah}

Guru SMK sebagai orang dewasa dan kebijakan SMK harus menerima bahwa ada agama lain selain agama yang dianutnya. Ada pemeluk agama lain selain dirinya yang juga memeluk suatu agama. Dalam sekolah yang muridnya beragam agama, SMK harus me-layani kegiatan rohani semua siswanya secara baik. Hilangkan kesan mayoritas minoritas siswa menurut agamanya. Setiap kegiatan keagamaan atau kegiatan apapun di SMK bia-sakan ada pembauran untuk bertoleransi dan membantu antar siswa yang beragama ber-beda. Guru dan kebijakan di SMK tidak mengungkapkan secara eksplisit, radikal, dan provokatif dalam wujud apapun, karena di luar sekolah itu siswa akan bertemu, bergaul, dan bekerjasama dengan orang lain yang berbeda agama. Sebagai bahan renungan, se-orang guru harus peka dan bijaksana men-jelaskan sejarah Perang Salib, bom Bali, konflik antar pemeluk agama di Maluku, teroris-me, dan sebagainya. Jangan sampai ada ketersinggungan sekecil apapun karena kecerobohan ungkapan guru. Sekecil apapun singgungan tentang agama akan membekas dalam benak siswa yang akan dibawanya sampai dewasa.

- Menghargai Keragaman Bahasa di Sekolah

Dalam suatu sekolah bisa terdiri dari guru, tenaga kependidikan, dan siswa yang berasal dari berbagai wilayah dengan ke-ragaman bahasa, dialek, dan logat bicara. Meski ada bahasa Indonesia sebagai bahasa pengantar formal di sekolah, namun logat atau gaya bicara selalu saja muncul dalam setiap ungkapan bahasa, baik lisan maupun tulisan. SMKperlu memiliki peraturan yang meng-akomodasi penghargaan terhadap perbedaan bahasa. Guru serta warga SMK yang lain tidak boleh mengungkapkan rasa "geli" atau "aneh" ketika mendengarkan atau membaca ungkapan bahasa yang berbeda dari kebiasa-annya. Semua warga SMK bersikap apresiatif dan akomodatif terhadap perbedaan-perbeda-an itu. Perbedaan yang ada seharusnya me-nyadarkan kita bahwa kita sangat kaya budaya, mempunyai teman-teman yang unik dan menyenangkan, serta dapat bertukar pe-ngetahuan berbahasa agar kita semakin kaya wawasan.

- Membangun Sikap Sensitif Gender di Sekolah

"Dasar perempuan, cerewet dan bisanya menangis!"."Mentang-mentang cowok, ja-ngan sok kuasa ngatur-ngatur di kelas ya!"."Syarat pengurus ekstrakurikuler adalah ketua haruscowok, sekretarisnyacewek,seksi per-lengkapancowok, seksi konsumsicewek,....".Contoh ungkapan-ungkapan itu harus dihapus dari benak dan kebiasaan guru, siswa, dan warga sekolah yang lain. Pembagian tugas, penyebutan 
contoh-contoh nama tokoh, dan sebagainya harus proporsional antara laki-laki dan perempuan. Tak ada yang lebih dominan atau sebaliknya minoritas antara gender lakilaki dan perempuan. Dengan tetap memper-timbangkan nilai-nilai kodrati, penerapan gender dalam fungsi-fungsi pembelajaran di SMKharus proporsional karena setiap siswa laki-laki dan perempuan memiliki potensi masing-masing. Perempuan jadi pemimpin, laki-laki mengurusi konsumsi, atau yang lain saat ini bukan sesuatu yang tabu. Siswa ber-hak mengembangkan potensinya dengan baik tanpa bayang-bayang persaingan gender. Re-ward dapat diberikan pada pada siapapun dengan gender apapun yang mampu ber-prestasi, sebaliknya beri punishmentyang tegas mendidik diberikan terhadap sikap, ucapan, dan perilaku yang menyinggung perbedaan gender

- Membangun Pemahaman Kritis dan Empati terhadap Ketidakadilan serta Perbedaan Sosial

Pelayanan pendidikan dan penegakan peraturan sekolah tidak boleh mempertimbangkan status sosial siswa. Siswa dibaurkan dari beragam status sosial dalam kelompok dan kelas untuk berinteraksi normal di sekolah. Meskipun begitu, guru dan siswa SMK harus tetap memahami perbedaan sosial yang ada di antara temantemannya. Pemahaman ini bukan untuk menciptakan per-bedaan, sikap lebih tinggi dari yang lain, atau sikap rendah diri bagi yang kurang, namun untuk menanamkan sikap syukur atas apapun yang dimiliki. Selanjutnya dikembangkan ke-pedulian untuk tidak saling merendahkan namun saling mendukung menurut ke-mampuan masing-masing. Sebaiknya sikap empati dan saling membantu tidak hanya ditanamkan di lingkungan sekolah saja. Suatu waktu siswa bisa diajak berkegiatan sosial di luar sekolah seperti di panti asuhan, panti jompo, dan sebagainya. Atau bila ada musibah di antara warga sekolah atau daerah lain siswa diajak berdoa dan memberikan sumbangan. Sekecil apapun doa, ucapan simpati, jabat tangan, pelukan, atau bantuan material akan sangat bermakna bagi pembentukan karakter siswa juga siapapun yang menjadi obyek empati.

- Membangun Sikap Anti Diskriminasi Etnis

Sekolah bisa jadi menjadi Indonesia mini atau dunia mini, dimana berbagai etnis menuntut ilmu bersama di sekolah. Di sekolah bisa jadi suatu etnis mayoritas terhadap etnis lainnya. Tapi perlu dipahami, di sekolah lain etnis yang semulamayoritas bisa jadi men-jadi minoritas. Hindari sikap negatif terhadap etnis yang berbeda. Sebagai misal ungkapan seperti ini, "Dasar Batak, ngeyel dan galak", "Heh si Aceh ya, slamat ya terhindar dari Tsunami", "Halo Papua Kritam (kriting dan hitam)", "Ssst, jangan dekat dengan orang Dayak, nanti dimakan Iho". Di SMKperlu di-tanamkan dan dibiasakan pergaulan yang positif, diberikan pemahaman bahwa inilah Indonesia yang hebat, warganya beraneka ragam suku atau etnis, bahasa, tradisi namun bisa bersatu karena sama-sama berbahasa Indo-nesia dan bangga menjadi bangsa Indonesia. Sebagai contoh bila bertemu saling bertegur sapa, "Halo Tigor, senang bertemu denganmu, kapan ya saya bisa berkunjung ke Danau Toba yang indah", "Wah, pemain bola dari Papua hebat-hebat ya, Emanuel Wanggai, Elly Eboy, dan lainnya. Suatu saat kamu bisa seperti me-reka", dan sebaginya. Karena itu perlu mem-bangun kultur dan kehidupan di SMK yang Bhinneka Tunggal Ika dengan interaksi dan komunikasi yang positif.

- Menghargai Perbedaan Kemampuan 
Tidak semua siswa berkemampuan sama atau standar. Dalam psikologi sosial di -kenal istilahdisability, artinya terdapat sebuah kondisi fisik dan mental yang membuat sese-orang kesulitan mengerjakan sesuatu yang orang kebanyakan dapat mengerjakannya de-ngan mudah. Dalam orientasi awal masuk dan pengamatan proses guru dan siswa dapat saling memahami kelebihan dan kelemahan masing-masing. Karena siswa SMKyang sudah menjadi bagian warga sekolah,jangan sampai sikap, ucapan, dan perilaku yang me-remehkan atau menter-tawakan kelemahan yang sudah dipahami. Hal itu sangat ber-dampak negatif, baik bagi siswa yang unggul maupun siswa yang lemah. Yang unggul akan merasajumawa dengan keunggulannya se-hingga bisa membuatnya lalai dan tidak ber-prestasi optimal. Bagi siswa yang lemah akan menjadi tidak termotivasi belajar dan merasa terkucilkan. Sebaiknya dibiasakanpembauran siswa unggul dan lemah dalam kelompok atau kelas agar terjadi pembimbingan sebaya, yang unggul semakin kuat pemahamannya tentang suatu materi dan merasa bermanfaat dengan ilmunya, serta yang kurang memperoleh guru sebaya yang lebih komunikatif dan merasa diterima oleh teman-temannya.

- Menghargai Perbedaan Umur

Setiap individu siswa mengalami per-tumbuhan fisik dan perkembangan kejiwaan-nya sesuai pertambahan umurnya. Guru SMK harus memahami ini, terutama tentang karak-teristik psikologis dan tingkat kemampuan sesuai umurnya. Sebagai misal kemampuan menganalisis masalah dan berkarya siswa SMK kelas $\mathrm{X}$ akan berbeda dengan kelas XI, apalagi dibandingkan dengan siswa kelas XII, atau gurunya. Selain itu jangan sampai ada deskriminasi, sikap, ucapan, dan perilaku ne-gatif diantara warga SMK dengan sebutan do-minasi senior atas yunior, pelecehan berdasar perbedaan ukuran fisik, kata sebutan atau panggilan yang tidak disukai (misal "si Unyil" untuk siswa bertubuh kecil, "bayi ajaib" untuk siswa berusia lebih muda tapi pintar, "tuyul" untuk adik kelas yang berkepala gundul, dan sebagainya). Seharusnya yang lebih tua mem-beri teladan, memberimotivasi, memberi ke-percayaan, demokratis, membimbing, meng-asuh, dan melindungi yang lebih muda. Yang muda menghormati, sopan santun, menau-ladani kebaikan, dan membantu yang lebih tua.

\section{Simpulan}

Dari paparan tersebut, dapat ditarik be-berapa kesimpulansebgai berikut. Pertama, Pendidikan multikultural di Indonesia sangat-lah penting, karena pendidikan multikultur ini berperan untuk menyatukan budaya bangsa, dalam arti tidak menjadikan budaya yang ada menjadi seragam, namun keberagaman yang dipandang sebagai kekayaan bangsa yang patut dijaga bersama. Jika peran dan tujuan tersebut tercapai secara maksimal, maka inte-grasi, persatuan dan kesatuan bangsa Indo-nesia akan tercapai.

Kedua, pendidikan multicultural adalah sebuah konsep yang dibuat dengan tujuan untuk menciptakan persamaan peluang pendi-dikan bagi semua siswa yang berbeda-beda ras, etnis, kelas sosial dan kelompok budaya. Tujuan penting lainnya dari konsep pendi-dikan multikultural adalah untuk membantu semua siswa agar memperoleh pengetahuan, sikap dan keterampilan yang diperlukan da-lam menjalankan peran-peran seefektif mung-kin pada masyarakat demokratik-pluralistik serta diperlukan 
untuk berinteraksi, negosiasi, dan komunikasi dengan warga dari kelompok be-ragam agar tercipta sebuah tatanan masya-rakat bermoral yang berjalan untuk kebaikan bersama. Melalui pendidikan multikultural pe-serta didik diharapkan dapat dengan mudah mema-hami, menguasai, memiliki kompetensi yang baik, bersikap dan menerapkan nilai-nilai demokratis, humanisme dan pluralisme di sekolah dan di luar sekolah.

Ketiga, pentingnya pendidikan multikultural diberikan kepada siswa SMKdengan harapan agar mereka mampu memahami bah-wa di dalam lingkungan mereka dan juga di lingkungan lain terdapat keragaman budaya. Keragaman budaya tersebut berpengaruh ter-hadap tingkah laku, sikap, pola pikir manusia sehingga manusia tersebut memiliki cara-cara (usage), kebiasaan (folk ways), aturan-aturan (mores) bahkan adat istiadat (customs) yang berbeda satu sama lain. Bila perbedaan itu tidak dapat dipahami dengan baik dan dite-rima dengan bijaksana, maka konflik (seperti perkelahian antar pelajar) akan mudah terjadi baik di lingkungan sekolah maupun di ling -kungan masyarakat.

Keempat, diperlukan suatu upaya pe-nerapan konsep yang sistematis dalam meng-atasi praktik dan problematik pembelajaran pendidikan multikultural, yaitu:(a) untuk mengaktualisasikan pendidikan multikultural haruslah memperhatikan berbagai dimensi yang saling berelasi satu sama lain.Dengan menggunakan panduan lima dimensi pen-didikan multikultur dari Banks, yaitu: inte-grasi materi (content integration), proses pem-bentukan pengetahuan (knowledge constru-ctionprocess), reduksi prasangka (prejudice reduction), pendidikan/perlakuan pedagogi tanpa pandang bulu (equity pedagogy), dan pemberdayaan budaya sekolah dan struktur sosial (empowering school culture and social structure), problematikyang timbul dapat di-atasi dengan upaya meningkatkan peran selu-ruh warga sekolah, terutama guru; (b) dengan menggunakan empat pendekatan dari Banks yang mengintegrasikan materi pendidikan multikultural ke dalam kurikulum ataupun pembelajaran di sekolah yang bila dicermati relevan untuk diimplementasikan di SMK, yaitu: (1) pendekatan kontribusi (the contributions approach), (2) pendekatan aditif (Adi-tive Approach), (3) pendekatan transformasi (the transformation approach), dan (4) pende-katanaksi sosial (the social action approach); (c) meningkatkan peran guru di dalam pen-didikan multikultural di SMK, di antaranya adalah sebagai berikut: (1) membangun para-digma keberagamaan inklusif di lingkungan sekolah, (2) menghargai keragaman bahasa di sekolah, (3) membangun sikap sensitif gender di sekolah, (4) membangun pemahaman kritis dan empati terhadap ketidakadilan serta per-bedaan sosial, (5)membangun sikap anti diskriminasi etnis, (6) menghargai perbedaan kemampuan, dan (7) menghargai perbedaan umur

\section{Referensi}

Banks, James A. (1993). Teaching strategies for ethnic studies. Boston: Allyn and Bacon Inc.

Banks, James A. (2002). An introduction to multicultural education. Boston: Allyn \& Bacon.

Banks, James A. (2007). Educating citizens in a multicultural society. New York: Teacher College Press. 
Zamroni. (2011). Pendidikan demokrasi pada masyarakat multikultural. Yogyakarta: gavin Kalam Utam

Hidayat, M. (2018). Problematika Internal Nelayan Tradisional Kota Padang: Studi Faktor -Faktor Sosial Budaya Penyebab Kemiskinan. Socius, 4(1), 31-40. doi:10.24036/scs.v4i1.15 